ISSN 1817-3721, E-ISSN 1818-8745

Plant Tissue Cult. \& Biotech. 28(2): 147-160, 2018 (December)

CBangladesh Assoc. for Plant Tissue Culture \& Biotechnology

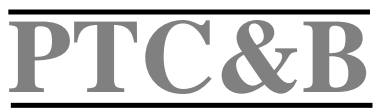

\title{
Efficient Adventitious Morphogenesis from In vitro Cultures of the Medicinal Plant Cymbopogon schoenanthus
}

\author{
Asmaa Abdelsalam, Kamal Chowdhury ${ }^{1}$ and Ahmed El-Bakry* \\ Department of Botany, Faculty of Science, Helwan University, Cairo 11795, Egypt
}

Key words: Biotin, Ca-pantothenate, Maltose, Medicinal plants, Methyl jasmonate,

\begin{abstract}
Cymbopogon schoenanthus subsp. proximus is a medicinal grass, the source of sesquiterpene proximadiol and is well known in folk medicine as renal antispasmodic. The effect of growth regulators, different sugar types, methyl jasmonate and vitamins on de novo organogenesis from seed cultures was studied. Among different concentrations of NAA and BA, $4 \mathrm{mg} / \mathrm{NAA}$ in combination with $0.5 \mathrm{mg} / \mathrm{BA}$ produced $100 \%$ callus induction. Both 1.0 and 4.0 $\mathrm{mg} / \mathrm{NAA}$ in combination with $0.5 \mathrm{mg} / \mathrm{BA}$ yielded the highest number of shoots. High concentration of sucrose $6 \%$ was efficient in root induction from organogenic shoots. Sugar types at a constant concentration of $3 \%$ had a significant effect on raising shoot numbers. Different concentrations of methyl jasmonate, biotin and Ca-pantothenate showed a decline in de novo shoot induction, but root formation frequency and numbers were significantly improved with all concentrations used.
\end{abstract}

\section{Introduction}

Cymbopogon schoenanthus subsp. proximus is a medicinal herb commonly known as Halfa bar, the plant is well known in folk medicine as diuretic, anti-diabetic and renal anti-spasmodic (Boulos 1983, Batanouny et al. 1999). Many researches proved that the plant extract of this subspecies possesses many biological activities (Selim 2011, El-Nezhawy 2014). The plant extract is rich with terpenoids mainly sesquiterpenes. The antispasmodic bioactive compound was identified as proximadiol (El-Askary et al. 2003).

*Author for correspondence: <ael_bakry@yahoo.com>. Biology Department, Claflin University, Orangeburg, SC 29115, USA

DOI: https://doi.org/10.3329/ptcb.v28i2.39674 
Plant in vitro culture is an ideal method to generate a large number of genetically uniform plants and also to conserve the rare and endangered plants (Sidhu 2010). This technique is also used widely to propagate a wide range of the medicinal plants like Allium sativum L., Aloe vera L. and Artimisia annua (Chaturvedi et al. 2007). In vitro regeneration of the genus Cymbopogon was reported for the economically important species, Cymbopogon winterianus was efficiently regenerated through callus culture using shoot tips and leaves as explants (Bobade et al. 2010), through organogenesis (Gahukar et al. 2014). Somatic embryogenesis of C. flexuosus was reported by (Nayak et al. 1996).

Sugar plays an essential role in in vitro plant growth and development, its accumulation inside the plant helps in new organ induction and differentiation (Gabryszewska 2010). Carbon source significantly affected somatic embryogenesis of Theobroma cacao (Da Silva et al. 2008) and indirect regenerated shoots from Pinuspinea (Sul 2004).

Plants produce vitamins to use them as intermediates in the biochemical reactions or as catalysts in different metabolic pathways. Biotin has an essential role as a cofactor and possesses a role in plant metabolism (Nikolau et al. 2003, Alban et al. 2000). Requirements of the vitamins concentrations in the plant tissue culture media differ from plant to plant and according to the type of culture (Abrahamian and Kantharajah 2011). Exogenous addition of other vitamins was found to improve regeneration capacity of some plants (Joy et al. 1988, Mehta et al. 2000). Role of vitamins in root induction and development has been reported in many studies (Drew et al. 1993, Der Krieken et al. 1992).

Methyl jasmonate (MeJa) is widely distributed in plant kingdom and its accumulation varied depending on the tissue type and function, developmental stage and in response to biotic and a biotic stress (Creelman and Mullet 1997). Effect of MeJa on Pharbitis nil growth, elongation of shoot and root was reported in Maciejewska and Kopcewicz (2002). Jasmonate enhanced the development of protocorm-like bodies from Cymbidium (Jaime et al. 2012) and enhanced shoot tip culture and rooting from Pistaciavera (Dolcet-Sanjuan and Claveria 1995).

Although C. schoenanthus subsp. proximus is of a high economic importance both in folk medicine and as the source of the bioactive sesquiterpene proximadiol, very few reports has been published on the species. The species is endangered due to extensive collection from the wild. The application of different biotechnology tools including in vitro culture, will aid in providing an alternative source for the bioactive compounds, propagules for ex situ conservation and a source of genetic variation for the species gene pool. Our present study reports an efficient organogenesis system of regeneration from in 
vitro cultures, that is a continuous with our previous efforts to establish different regeneration systems for the species. We studied the effect of different concentration of growth regulators, vitamin types and concentrations, sugar types and methyl jasmonate on organogenesis. We report an efficient, short-term regeneration system that can be used for the production of bioactive compounds and as a source for genetic conservation.

\section{Materials and Methods}

Seeds were collected from Aswan University, Egypt in March 2014 and stored in paper bags in the dark at $25^{\circ} \mathrm{C}$.

Tissue culture media were purchased from Phyto-Technology (USA). Plant growth regulators, methyl jasmonate, sugars and vitamins were purchased from Sigma Aldrich (St. Louis, MO, USA).

Surface sterilized seeds (El-Bakry and Abdelsalam 2012) were cultured on Murashige and Skoog MS salts (1962) with Gamborg's B5 vitamins (Gamborg et al. 1968) (MSB5) supplemented with different concentrations of NAA (0.5, 1.0, 2.0, 4.0, and $8.0 \mathrm{mg} /$ ) in combination with two different concentrations of BA $(0.2,0.5 \mathrm{mg}$ A). Subculture was carried out after 4 weeks on the same media. Regenerated shoots cultured on MSB5 medium with $4.0 \mathrm{mg} / \mathrm{NAA}$ and $0.5 \mathrm{mg} /$ BA were transferred after four weeks to rooting media supplemented with different concentration from NAA $(0.0,0.1,0.2 \mathrm{mg} \Lambda)$ in combination with 2 sucrose concentrations 3 and $6 \%$. Number of shoots and roots were screened after 4 and 8 weeks. Plantlets developed on solid media were screened and acclimatized after 12 weeks from seed culture.

Effect of different sugar types: MSB5 medium supplemented with $4 \mathrm{mg} /$ NAA, $0.5 \mathrm{mg} / \mathrm{BA}$ and $3 \%$ sugars: fructose, glucose, lactose, maltose and sucrose were used separately with surface sterilized seeds culture. Subcultures were carried out after 4 weeks onto the same media composition and sugar type. Eight weeks old cultures were transferred to hormone free media with $6 \%$ sugar concentration. Twelve weeks old plantlets were screened and acclimatized.

Effect of different methyl jasmonate concentrations: Surface sterilized seeds were cultured on media supplemented with $4 \mathrm{mg} / \mathrm{NAA}, 0.5 \mathrm{mg} / \mathrm{BA}$ and different concentrations from methyl jasmonate $(0.02,2.24,22.4,44.8 \mathrm{mg} \Lambda)$. Subcultures were carried out after 4 weeks on the same media. All cultures were screened for number of shoots and roots after 4 weeks from first subculture.

Effect of Ca-panthothenate and biotin: Seeds were cultured on media supplemented with $4 \mathrm{mg} / \mathrm{NAA}, 0.5 \mathrm{mg} / \mathrm{BA}$ and different concentrations from each of Ca-panthothenate and biotin $(0.5,1.0,1.5,2.0 \mathrm{mg} /)$. Subculture was 
carried out after 4 weeks on the same media. Explants were screened for root number after 4 weeks from first subculture.

Healthy plantlets from the experiments (effect of NAA concentrations and sugar types) were carefully removed from the Magenta box and excess medium removed by washing with tap water. Plantlets were transferred to pots containing garden soil, covered with polyethylene bags to maintain high humidity. Plantlets were watered daily with tap water and incubated at $25^{\circ} \mathrm{C}$ under white fluorescent light for one week. Humidity was gradually decreased. After eight weeks plants were transferred to the greenhouse under ambient condition with programmed watering.

For each experiment, data were collected from each seed explant on number of shoots, fresh weight and dry weight. For each treatment, data were collected from 16 - 32 seed explants cultured in 4 - 8 Magenta boxes with 4 seeds in each. Data were analyzed using Minitab 17 software by one way ANOVA. Treatment means were compared by Fisher least significant difference (LSD) method with 95\% confidence level.

\section{Results and Discussion}

Different physiological treatments were used to initiate and control adventitious organogenesis from C. schoenanthus subsp. proximus cultures. Using NAA and BA in different concentrations, followed by culturing on maltose selected as a carbon source, we were able to produce shoots efficiently within 6 weeks. This was followed by successful rooting on high sucrose concentration and greenhouse acclimatization (Fig. 5). Adventitious roots were produced on the addition of each of Ca-pantothenate, biotin and methyl jasmonate to the culture media in the presence of growth regulators. Such roots are a potential rich source of bioactive compounds.

Callus developed on MSB5 medium supplemented with different concentrations of NAA and BA. After three weeks of seed culturing, the highest callus formation response frequency $(100 \%)$ was obtained from MSB5 medium supplemented with $4 \mathrm{mg} / \mathrm{NAA}$ and $0.5 \mathrm{mg} / \mathrm{BA}$ (Fig. 1).

Number of indirect regenerated shoots and roots were recorded after one and eight weeks of seed culture are shown in Table 1. After four weeks of culture, the best mean number of shoots $(5.0 \pm 2.8$ shoot/explant $)$ was observed on a medium supplemented with $0.5 \mathrm{mg} \Lambda$ NAA in combination with $0.5 \mathrm{mg} \Lambda$ $\mathrm{BA}$, after 8 weeks both 1.0 and $4.0 \mathrm{mg} / \mathrm{NAA}$ in combination with $0.5 \mathrm{mg} \Lambda \mathrm{BA}$ gave the highest mean number of shoots $5.00 \pm 0.2$ and $4.50 \pm 0.4$, respectively. Auxin is required in polar growth of all organ primordia (Benjamins and Scheres 
2008, Delker et al. 2008). Auxins play an important role in axillary meristem initiation in vegetative branching of grasses (McSteen 2010). Biosynthesis and transport of auxins have an important role in stem elongation, leaf initiation and development. Reduction in auxin transportation decreased internodes length in mutant maize (Phillips et al. 2009), narrow leaf and dwarf stem in mutant rice (Qi et al. 2008) and decreased number of leaves in Arabidopsis (Bennett et al. 1995). Auxin has a role in the control of tiller angle in rice, which enhanced rice growth and density (Wang et al. 2007). Indirect organogenesis from Vitex trifolia plant required higher concentration from BA comparing with NAA in the culture medium support indirect organogenic shoot formation (Arulnndam and Ghanthikumar 2011).

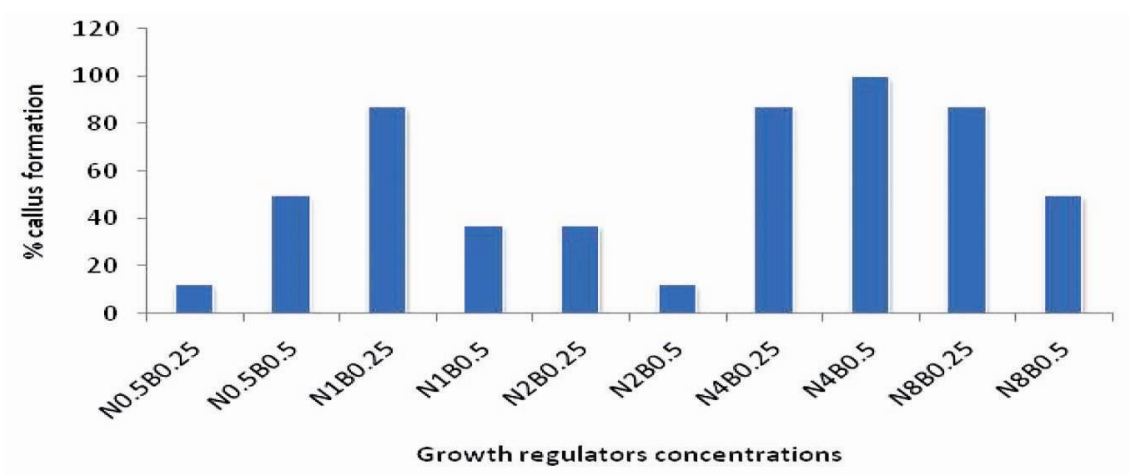

Fig. 1. Effect of different concentrations $(\mathrm{mg} /)$ from NAA $(\mathrm{N})$ and $\mathrm{BA}(\mathrm{B})$ on percentage of morphogenetic callus after three weeks of seed callus culture initiation.

In rooting stage, higher concentrations of NAA $4.0 \mathrm{mg} /$ with $0.5 \mathrm{mg} / \mathrm{BA}$ and $8.0 \mathrm{mg} / \mathrm{NAA}$ with $0.25 \mathrm{mg} / \mathrm{BA}$ produced highest mean number of roots $1.71 \pm 0.5$ and $0.75 \pm 0.5$, respectively. Healthy shoots $(2-3 \mathrm{~cm}$ length) produced on MSB5 medium with $4.0 \mathrm{mg} / \mathrm{BA}$ and $0.5 \mathrm{mg} / \mathrm{BA}$ were transferred after 8 weeks to a rooting medium composed of MSB5 medium fortified with different concentrations of sucrose and NAA. The results indicated that different concentrations of NAA did not show a significant difference $(\mathrm{p}<0.05)$. However, result from higher concentration of sucrose $(6 \%)$ was significantly better than that of $3 \%$ with $p$ value $=0.08$. Higher concentrations from sucrose in combination with $0.1 \mathrm{mg} / \mathrm{NAA}$ produced higher mean number of roots $7.0 \pm 2.0$ roots/explant (Table 2). Similar result of enhanced root formation from regenerated sugarcane shoots cultured in medium containing high concentration of sucrose (5\%) was reported (Gopitha et al. 2010), glucose with 9\% concentrations induced root proliferation in Peonies plants (Gabryszewska 2010), 
number and length of apple plants roots increased when cultured in media supplemented with higher concentration of sucrose (Bahmani et al. 2009).

Table 1. Effect of different concentrations (mg/l) of NAA (N) and BA (B) on organogenesis, from seed callus cultures, 4 and 8 weeks from culture initiation.

\begin{tabular}{lllllll}
\hline \multirow{2}{*}{ Treatments } & \multicolumn{3}{c}{4 weeks } & & \multicolumn{2}{c}{8 weeks } \\
\cline { 2 - 3 } \cline { 6 - 7 } & No. of shoots & No. of roots & & No. of shoots & No. of roots \\
\hline N0.5B0.25 & $0.11 \pm 0.1 \mathrm{~b}$ & $0.00 \pm 0.00 \mathrm{c}$ & & $2.92 \pm 0.6 \mathrm{abc}$ & $0.00 \pm 0.0 \mathrm{~b}$ \\
N0.5B0.5 & $5.00 \pm 2.8 \mathrm{a}$ & $0.08 \pm 0.07 \mathrm{abc}$ & & $1.50 \pm 0.7 \mathrm{abc}$ & $0.00 \pm 0.0 \mathrm{~b}$ \\
N1B0.25 & $3.06 \pm 1.4 \mathrm{ab}$ & $0.13 \pm 0.1 \mathrm{abc}$ & & $3.08 \pm 1.6 \mathrm{abc}$ & $0.00 \pm 0.0 \mathrm{~b}$ \\
N1B0.5 & $2.35 \pm 0.9 \mathrm{ab}$ & $0.00 \pm 0.0 \mathrm{c}$ & & $5.00 \pm 0.2 \mathrm{a}$ & $0.00 \pm 0.0 \mathrm{~b}$ \\
N2B0.25 & $0.00 \pm 0.0 \mathrm{~b}$ & $0.00 \pm 0.0 \mathrm{c}$ & & $0.35 \pm 0.7 \mathrm{c}$ & $0.00 \pm 0.0 \mathrm{~b}$ \\
N2B0.5 & $0.71 \pm 0.4 \mathrm{ab}$ & $0.00 \pm 0.0 \mathrm{c}$ & & $2.21 \pm 0.4 \mathrm{abc}$ & $0.00 \pm 0.0 \mathrm{~b}$ \\
N4B0.25 & $0.17 \pm 0.1 \mathrm{~b}$ & $0.00 \pm 0.0 \mathrm{c}$ & & $1.00 \pm 1.3 \mathrm{bc}$ & $0.00 \pm 0.0 \mathrm{~b}$ \\
N4B0.5 & $3.19 \pm 0.7 \mathrm{ab}$ & $2.10 \pm 1.0 \mathrm{ab}$ & & $4.50 \pm 0.4 \mathrm{ab}$ & $1.71 \pm 0.5 \mathrm{a}$ \\
N8B0.25 & $0.47 \pm 0.2 \mathrm{~b}$ & $2.00 \pm 0.8 \mathrm{a}$ & & $1.25 \pm 0.8 \mathrm{abc}$ & $0.75 \pm 0.5 \mathrm{ab}$ \\
N8B0.5 & $0.78 \pm 0.3 \mathrm{ab}$ & $0.06 \pm 0.04 \mathrm{bc}$ & & $2.50 \pm 0.6 \mathrm{abc}$ & $0.00 \pm 0.0 \mathrm{~b}$ \\
\hline
\end{tabular}

In each column means followed by the same letter are not significantly different at $\mathrm{p}<0.05$ according to Fisher test.

Table 2. Effect of different sucrose concentrations in combination with NAA on root formation of adventitious shoots initiated from seed callus cultures after 12 weeks.

\begin{tabular}{lcc}
\hline $\begin{array}{l}\text { Sucrose conc. } \\
(\%)\end{array}$ & $\begin{array}{c}\text { NAA } \\
(\mathrm{mg} /)\end{array}$ & $\begin{array}{c}\text { Root number/ } \\
\text { explant }\end{array}$ \\
\hline 3 & 0.0 & $0.0 \pm 0.0 \mathrm{~b}$ \\
& 0.1 & $0.0 \pm 0.0 \mathrm{~b}$ \\
& 0.2 & $0.0 \pm 0.0 \mathrm{~b}$ \\
6 & 0.0 & $5.5 \pm 1.4 \mathrm{ab}$ \\
& 0.1 & $7.0 \pm 2.0 \mathrm{a}$ \\
& 0.2 & $4.5 \pm 3.4 \mathrm{ab}$ \\
\hline
\end{tabular}

Means followed by the same letter are not significantly different at $\mathrm{p}<0.05$ according to Fisher test.

Sugar types at $3 \%$ concentration were highly significant on indirect regeneration of shoots and subsequent rooting (Fig. 2) at $\mathrm{p}=0.0$. Maltose gave rise to the best mean number of shoots $(13.5 \pm 0.7$ shoots/explant $)$ after eight weeks. On the other hand, the highest mean number of roots $(12.4 \pm 1.0$ roots/explant) was obtained from MSB5 medium supplemented with sucrose 
(Table 3). Our previous results reported that maltose was the best sugar in somatic embryogenesis (Abdelsalam et al. 2015) and micropropagation of $C$. schoenanthus subsp. proximus (Abdelsalam et al. 2017). Maltose produced the best results in shoot induction from soybean callus culture (Sairam et al. 2003), and is considered as a favorable sugar for in vitro plant regeneration of many grasses including, rice and wheat (Last and Brettell 1990, Navarro-Alvarez et al. 1994). In maize plant regeneration, both maltose and sucrose showed better results in shoot and root induction experiments (Gauchan 2012). Maltose enhanced embryo induction four times higher than sucrose in wheat anther culture (Last and Brettell 1990). Maltose enhanced shoot proliferation from protoplast derived tissue of indica and japonica rice varieties (Jain et al. 1997).

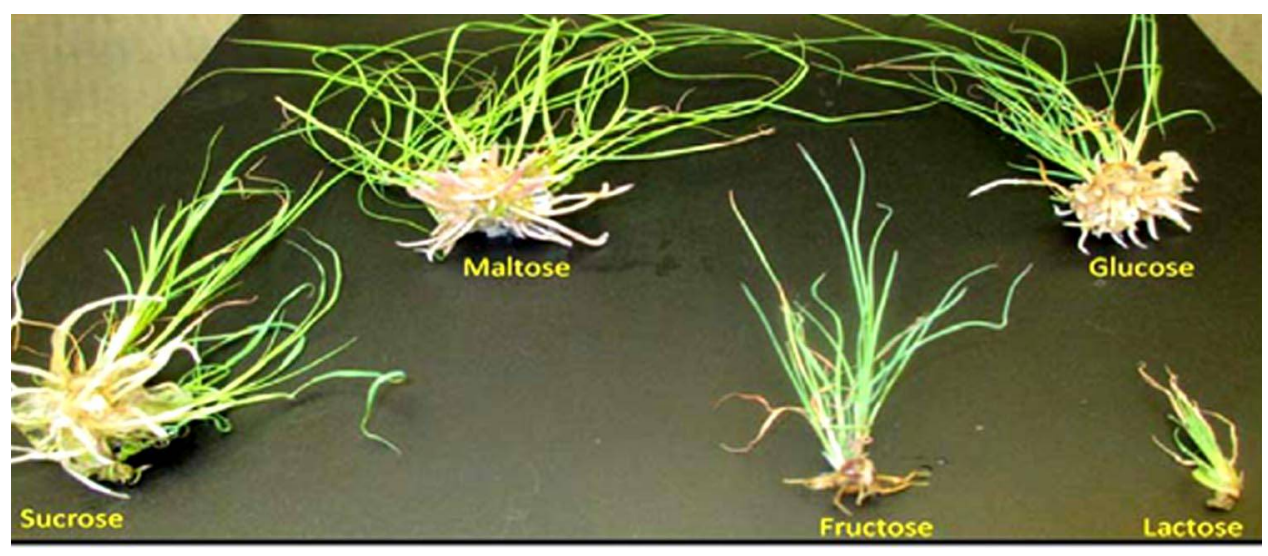

Fig. 2. Effect of different sugar types, at 3\% concentration, on organogenesis from seed callus cultures after 12 weeks.

Table 3. Effect of sugar types (3\% concentration) on organogenesis (adventitious shoots and roots) after 12 weeks from initial seed culture.

\begin{tabular}{lll}
\hline Sugar type & Shoot number & Root number \\
\hline Fructose & $4.8 \pm 0.4 \mathrm{c}$ & $3.3 \pm 0.6 \mathrm{c}$ \\
Glucose & $7.7 \pm 1.2 \mathrm{~b}$ & $8.5 \pm 1.3 \mathrm{~b}$ \\
Lactose & $1.9 \pm 0.2 \mathrm{~d}$ & $0.0 \pm 0.0 \mathrm{~d}$ \\
Maltose & $13.5 \pm 0.7 \mathrm{a}$ & $8.2 \pm 0.8 \mathrm{~b}$ \\
Sucrose & $7.3 \pm 0.2 \mathrm{~b}$ & $12.4 \pm 1.0 \mathrm{a}$ \\
\hline
\end{tabular}

In each column means followed by the same letter are not significantly different at $\mathrm{p}<0.05$ according to Fisher test.

Effect of methyl jasmonate on indirect regeneration is shown in Table 4, Fig. 4B. Methyl jasmonate had an inhibitory effect on shoot production; shoot induction was retarded or completely inhibited using $0.02 \mathrm{mg} \Lambda$ MeJa in the 
culture media. Although, for rhizogenesis $2.24 \mathrm{mg} / \mathrm{MeJa}$ gave the highest mean number of regenerated roots $(13.33 \pm 3.40)$, the data were not statistically significant different when compared to control and other concentrations. Exogenous addition of methyl jasmonate inhibited the in vitro shoot regeneration of tobacco and leaf blade formation of lily bulbs plants (Biondi et al. 2001, Jasik and Klerk 2006). Certain concentration from methyl jasmonate reduced shoot formation in thin cell layer tobacco culture through over inducing of mitotic division and cell expansion around shoot primordia leading to thickening and suberization (Capitani et al. 2005). MeJa also showed an inhibitory effect in different stages from somatic embryogenesis of Medicago sativa (Rudus et al. 2006). MeJa was reported to produce an antagonistic effect on cytokinin activity in many studies such as, inhibition of anti-senescence effect of $\mathrm{Kn}$ in oat, and effect of cytokinin in soyabean callus growth (Ueda and Kato 1982).

Table 4. Effect of methyl jasmonate concentrations (mg/l) on organogenesis after 8 weeks from initial seed culture.

\begin{tabular}{lll}
\hline $\begin{array}{l}\text { Methyl jasmonate } \\
\text { concentration }\end{array}$ & $\begin{array}{c}\text { No. of } \\
\text { shoots }\end{array}$ & $\begin{array}{c}\text { No. of } \\
\text { roots }\end{array}$ \\
\hline 0.0 & $13.00 \pm 0.91 \mathrm{a}$ & $6.00 \pm 1.73 \mathrm{ab}$ \\
0.02 & $0.00 \pm 0.00 \mathrm{c}$ & $6.17 \pm 2.07 \mathrm{ab}$ \\
2.24 & $3.08 \pm 0.95 \mathrm{bc}$ & $13.33 \pm 3.40 \mathrm{a}$ \\
22.4 & $4.00 \pm 1.15 \mathrm{~b}$ & $7.08 \pm 1.76 \mathrm{ab}$ \\
44.8 & $0.83 \pm 0.28 \mathrm{bc}$ & $1.25 \pm 0.51 \mathrm{~b}$ \\
\hline
\end{tabular}

In each column means followed by the same letter are not significantly different at $p<0.05$ according to Fisher test.

Effect of different concentrations of Ca-pantothenate and biotin on indirect organogenesisis is shown in Figs 3 and 4C-D. Although none of the vitamin treatments showed any organogenic shoot regeneration, root number was enhanced in media supplemented with vitamins. Lower concentration of Capantothenate $(0.5,1.0 \mathrm{mg} \Lambda)$ yielded a higher mean number of roots compared to the same concentration of biotin. Moreover, higher concentrations of biotin (1.5, $2.0 \mathrm{mg} \Lambda$ ) were better than their respective concentrations from Ca-pantothenate and control. $1.5 \mathrm{mg} / \mathrm{biotin}$ produced the best mean number of roots $(17.00 \pm 4.04$ roots/explant). Roots of Cymbopogon species are important source of terpenoids. Roots extract from Cymbopogon citratus contained 10 sesquiterpenoid that differed in their chemical composition than those present in shoots ( $\mathrm{Li}$ et al. 2005). Cymbopogon nardus root extract contained the greatest inhibitory activity in comparing with leaf and stalk (Suwitchayanon et al. 2014). 


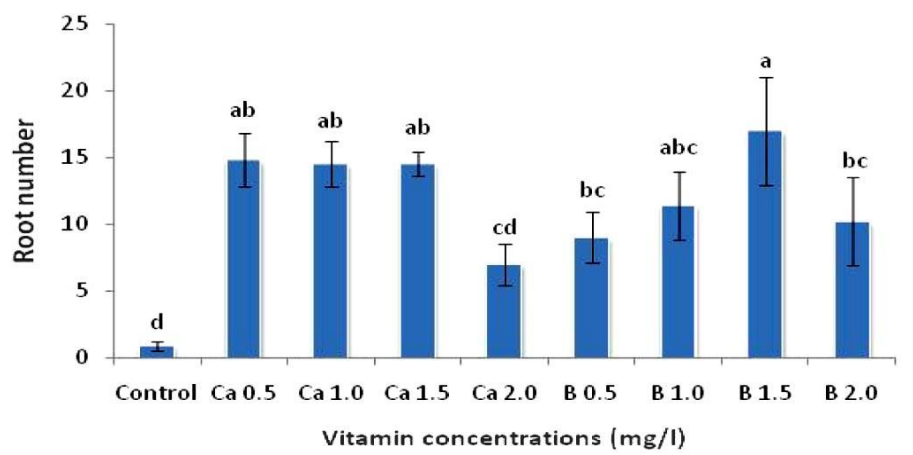

Fig. 3. Effect of different concentrations ( $\mathrm{mg} /$ ) from Ca-pantothenate $(\mathrm{Ca})$, biotin $(\mathrm{B})$ on rhizogenesis after 8 weeks from culture. *Means followed by the same letter are not significantly different at $\mathrm{p}<0.05$ according to Fisher test.
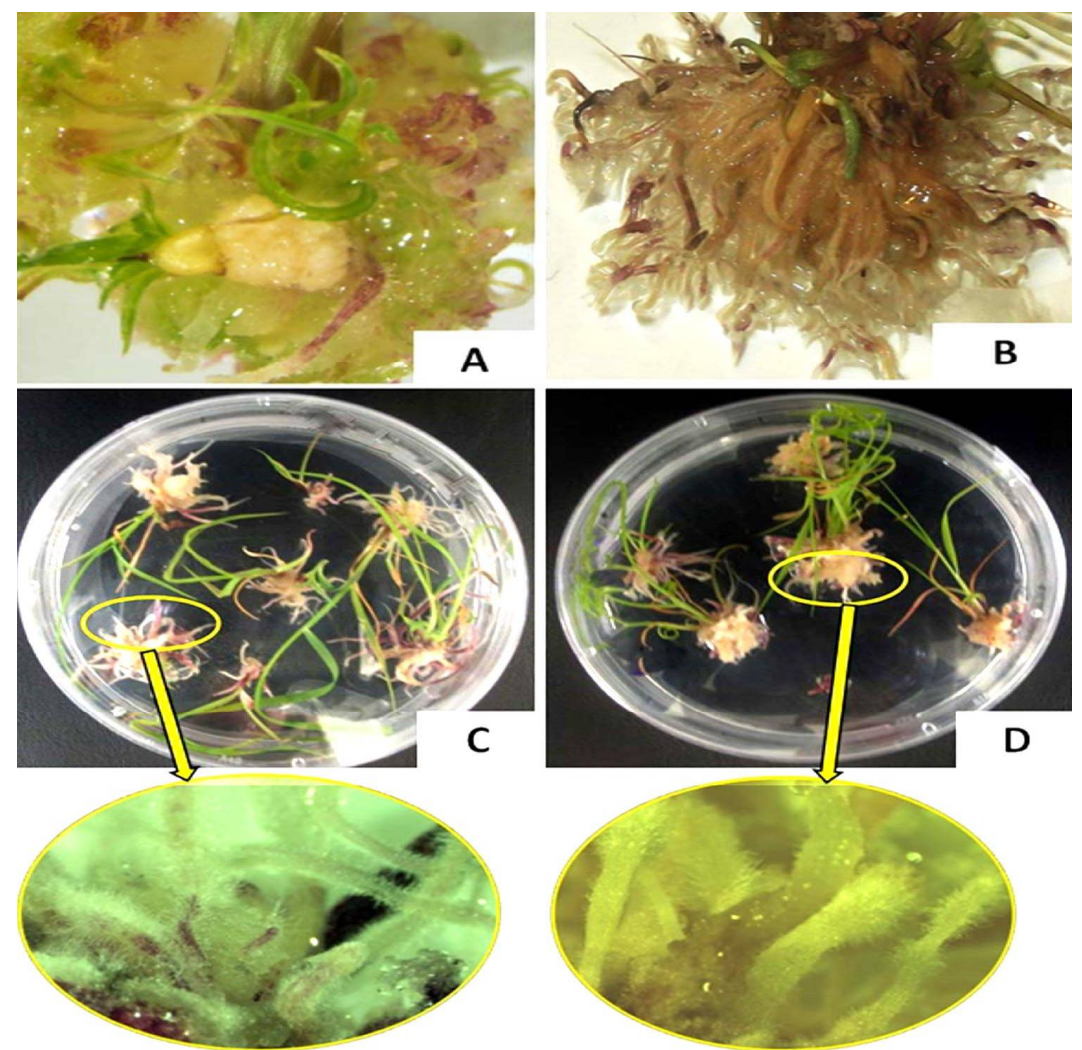

Fig. 4. Effect of vitamins and methyl jasmonate on organogenesis: (A) control (4.0 mg/ $\mathrm{NAA}+0.5 \mathrm{mg} / \mathrm{BA}$ ). (B) A+ $2.24 \mathrm{mg} /$ methyl jasmonate. (C) A+1.5 mg/ biotin with magnified parts from adventitious roots. (D) A+1.0 $\mathrm{mg} /$ Ca-pantothenate with magnified parts from adventitious roots. Note the presence of many adventitious shoots in the control, while other treatments contain mainly roots in addition to embryonic shoots. 
The effect of vitamins in organ induction and developments were widely described in previous studies. Biotin enhanced root growth of Cymbidium and improved the colonization of alfalfa roots (Streit et al. 1996). Ca-pantothenate and biotin enhanced plant regeneration through organogenesis of Cymbopogon martinii (Baruah and Bordoloi 1989). Addition of coconut water and biotin to the culture medium also significantly enhanced shoot bud induction and multiplication from Cymbopogon pendulus (Bhattacharya et al. 2010). Thiamine improved root formation in Taxus species (Chee 1995). Addition of vitamin E in Eucalyptus tissue culture media enhanced adventitious root formation (Roux et al. 1991).
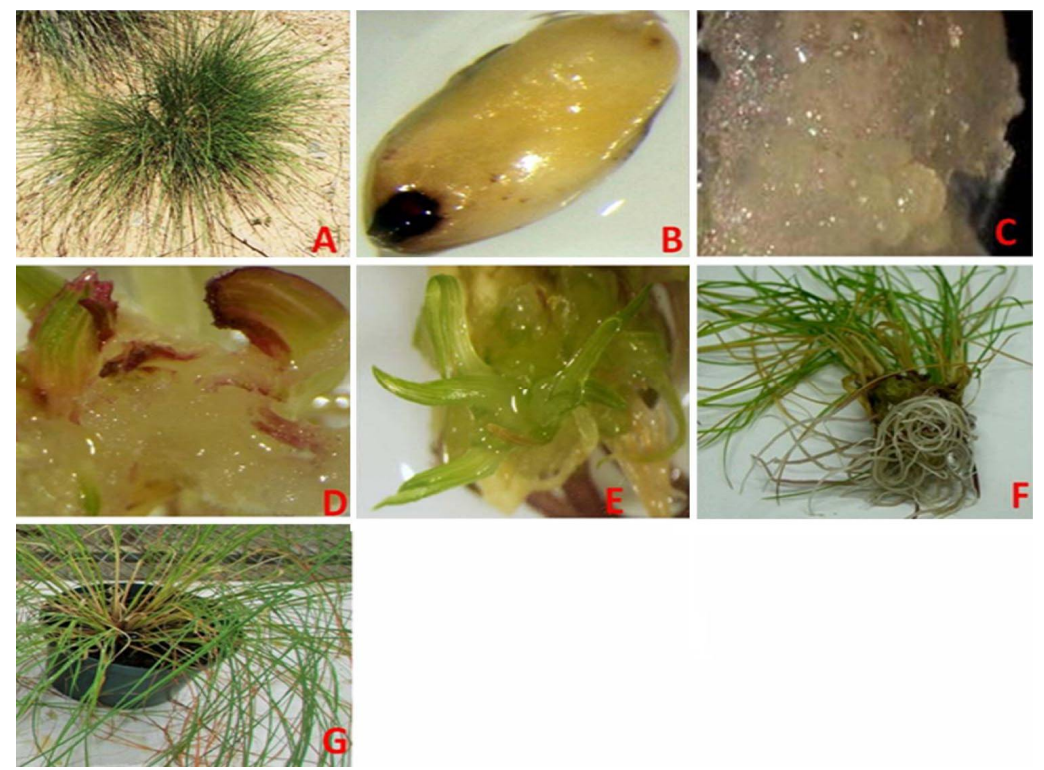

Fig. 5. Regeneration through indirect organogenesis: (A) Wild plant. (B) Mature seed. (C) Undifferentiated callus one week old. (D) Callus with organogenic shoots 4-5 weeks old. (E) Organogenic shoots 6-8 weeks. (F) Twelve weeks old rooted shoots on $6 \%$ sucrose. $(G)$ Thirty-week acclimatized plant growing in the greenhouse.

The use of in vitro cultures is important in the genetic manipulation, conservation of species, for the production of bioactive compounds and as a source of variation for different characters. In the present work, we established an efficient, short term de novo regeneration system that can be used for propagation, ex situ conservation, as a source of bioactive compounds and a potential source of variation for the species. Shoots in high numbers $(13.5 \pm 0.7$ shoots/explant) were produced when maltose was used as carbon a source and acclimatized plants were successfully established in the greenhouse within 3 months. 
Sensitivity of the species tissues to auxins was demonstrated on two occasions: (a) The use of NAA at high concentrations than BA resulted in shoot regeneration both directly from zygotic embryo germination, mixed with adventitious shoots produced from seed callus tissue. Tillering in grasses both in vivo and in vitro has been shown be positively affected by auxins. (b) The interaction between NAA and each of Ca-pantothenate and biotin, where the vitamins used seemed to nullify the ability of auxins to produce de novo shoots, and exhibited high ability for adventitious root production. Producing adventitious roots using different vitamins treatments can be used to enrich the production of the bioactive terpenoids in vitro and can lead to future studies with hairy root culture transformation of the species for the production of such bioactive compounds.

Due to the known relatively narrow geographical distribution of Cymbopogon schoenanthus subsp. proximus in sub-tropical Africa, and due to the harsh climatic conditions in such natural habitats, the present work may aid in producing genetic variation, within a relatively short time span, that can be useful for the production of different bioactive compounds. It can also provide propagules for ex situ conservation.

\section{Acknowledgements}

This work was financially supported by Grant \#79 from the Egyptian Academy of Scientific Research and Technology, Plant Biotechnology and Genetic Engineering program and the Culture Affairs and Missions Sector, Ministry of Higher Education, to whom the authors are grateful.

\section{References}

Abdel-Salam AM, Chowdhury K and El-Bakry AA (2015) Effect of sugar types, culture age, concentrations of 2, 4-D and sucrose on somatic embryogenesis of Cymbopogon schoenanthus subsp. proximus. Plant Tissue Cult. Biotechnol. 25: 51-62.

Abdel-Salam AM, Chowdhury K and El-Bakry AA (2017) Micropropagation through in vitro tillering from seed cultures of the medicinal Plant Cymbopogon schoenanthus subsp. proximus. Asian J. Applied Sciences 5: 31-40.

Abrahamian P and Kantharajah A (2011) Effect of vitamins on in vitro organogenesis of plant. Amer. J. Plant Sci. 2: 669- 674.

Alban C, Job D and Douce R (2000) Biotin metabolism in plants. Annu. Rev. Plant Physiol. Plant Mol. Biol. 51: 17-47.

Arulnndam JP and Ghanthikumar S (2011) Indirect organogenesis of Vitex trifolia Linn.an important medicinal plant. Indian J. Nat. Prod. Resour. 2: 261-264. 
Bahmani R, Karami O and Gholami M (2009) Influence of carbon sources and their concentrations on rooting and hyperhydricity of apple rootstock MM 106. World Appl. Sci. J. 6: 1513-1517.

Baruah A and Bordoloi DN (1989) High frequency plant regeneration of Cymbopogon martinii (Roxb.) Wats by somatic embryogenesis and organogenesis. Plant Cell Rep. 8: 483-485.

Batanouny KH, Abou-Tabl S, Shabana M and Soliman F (1999) Wild medicinal plants in Egypt. An inventory to support conservation and sustainable use. Academy of Scientific Research and Technology, Egypt International Union for Conservation (IUCN).

Benjamins R and Scheres B (2008) Auxin: The looping star in plant development. Ann. Rev. Plant Biol. 59: 443-65.

Bennett SRM, Alvarez J, Bossinger G and Smyth DR (1995) Morphogenesis in pinoid mutants of Arabidopsis thaliana. The Plant Journal 8: 505-520.

Bhattacharya S, Bandopadhyay TK and Ghosh PD (2010) Somatic embryogenesis in Cymbopogon pendulus and evaluation of clonal fidelity of regenerates using ISSR marker. Sci. Hort. 123: 505-513.

Biondi S, Scaramagli S, Capitani F, Altamura MM and Torrigani P (2001) Methyl jasmonate up regulates biosynthetic gene expression, oxidation and conjugation of polyamines and inhibit shoot formation in tobacco thin layer. J. Expt. Bot. 52: 231-242.

Bobade BR, Kamdi SRA and Wadhai VS (2010) In vitro shoot regeneration studies in Java citronella. Asian J. Biol. Sci. 5: 216-218.

Boulos L (1983) Medicinal Plants of North Africa. Reference Publication Inc. Michigan.

Capitani F, Biondi S, Falasca G, Ziosi V, Balestrazzi A, Carbonera D, Torrigian P and Altamura MM (2005) Methyl jasmonate disrupts shoot formation in tobacco thin cell layers by over-inducing mitotic activity and cell expansion. Planta 220: 507-519.

Chaturvedi HC, Jain M and Kidwai NR (2007) Cloning of medicinal plants through tissue culture - A review. Indian J. Expt. Biol. 45: 937-948.

Chee PP (1995) Organogenesis in Taxus brevifolia tissue cultures. Plant Cell Report 14: 753757.

Creelman RA and Mullet JE (1997) Biosynthesis and action of jasmonates in plants. Annu. Rev. Plant Physiol. Plant Molecular Biology 48: 355-381.

Da Silva TER, Cidade LC, Alvim FC, Cascardo JCM and Costa MGC (2008) Somatic embryogenesis and plant regeneration in elite clones of the Obroma cacao. Pesquisa Agropecuária Brasileira 43: 1433-1436.

Delker C, Raschke A and Quint M (2008) Auxin dynamics: The dazzling complexity of a small molecule's message. Planta 227: 929-941.

Der Krieken VWM, Breteler H, Visser MHM and Jordi W (1992) Effect of light and riboflavin on indole butyric acid-induced root formation on apple in vitro. Physiol. Plant 85: 589-594.

Dolcet-Sanjuan R and Claveria E (1995) Improved shoot tip micropropagation of Pistacia vera $\mathrm{L}$. and the beneficial effects of methyl jasmonate. J. Amer. Soc. Hortic. Sci. 120: 938-942. 
Drew RA, McComb JA and Considine JA (1993) Rhizogenesis and root growth of Carica papaya L. in vitro in relation to auxin sensitive phases and use of riboflavin. Plant Cell Tissue Organ Cult. 33: 3-7.

El-Askary HI, Meselhy MR and Galal AM (2003) Sesquiterpenes from Cymbopogon proximus. Molecules 8: 670-677.

El-Bakry AA and Abelsalam AM (2012) Regeneration from embryogenic callus and suspension cultures of the wild medicinal plant Cymbopogon schoenanthus. Afr. J. Biotechnol. 11: 10098-10107.

El-Nezhawy AOH, Maghrabic IA, Mohamed KM and Omar HA (2014) Cymbopogon proximus extract decreases L-NAME-induced hypertension in rats. Int. J. Pharm Sci. Rev. Res. 27: 66-69.

Gabryszewska E (2010) The effect of glucose and growth regulators on the organogenesis Paeonia lactiflora Pall. in vitro. J. Fruit Ornam. Plant Res. 18: 309-320.

Gahukar SJ, Bansod SM and Akhare AA (2014) An efficient protocol for in vitro regeneration in java citronella (Cymbopogon winterianus) through callus. Asian J. Biol. Sci. 9: 267-272.

Gamborg OL, Miller RA and Ojima K (1968) Nutrient requirements of suspension culture of soybean root cells. Exp. Cell Res. 50: 151-158.

Gauchan DP (2012) Effect of different sugars on shoot regeneration of maize (Zea mays) Kathmandu University Journal of Science Engineering and Technology 8: 119-124.

Gopitha K, Bhavani AL and Senthilmanickam J (2010) Effect of the different auxins, cytokinins in callus induction, shoot, root regeneration in sugarcane. Int. J. Pharm. Biol. Sci. 1: 1-7.

Jaime A and DA Silva T (2012) Impact of methyl jasmonate on PLB formation of hybrid Cymbidium (Orchidaceae). J. Plant Develop. 19: 47-52.

Jain RK, Davey MR, Cocking EC and Wu R (1997) Carbohydrate and osmotic requirements for high frequency plant regeneration from protoplast-derived colonies of indica and japonica rice varieties. J. Expt. Bot. 48: 751-758.

Jasik J and de Klerk G (2006) Effect of methyl jasmonate on morphology and dormancy development in lily bulblets regenerated in vitro. Plant Growth Regul. 25: 45-51.

Joy RW, Patel KR and Thorpe TA (1988) Ascorbic acid enhancement of organogenesis in tobacco callus. Plant Cell Tiss. Org. Cult. 13: 219-228.

Last DI and Brettell RI (1990) Embryo yield in wheat anther culture is influenced by the choice of sugar in the culture medium. Plant Cell Rep. 9: 14-6.

Li H, Huang J, Zhang X, Chen Y, Yang J and Hei L (2005) Allelopathic effects of Cymbopogon citratus volatile and its chemical components. Ying Yong Sheng Tai Xue Bao. 16: 763-767

Maciejewska B and Kopcewicz J (2002) Inhibitory effect of methyl jasmonate on flowering and elongation growth on Pharbitis nil. J. Plant Growth Regul. 21: 216-223.

McSteen P (2010) Auxin and monocot development. Cold Spring Harbor Perspectives in Biology 2: 1-17.

Mehta UJ, Krishnamurthy KV and Hazra S (2000) Regeneration of plants via adventitious bud formation from mature zygotic embryo axis of tamarind (Tamarindus indica L.). Curr. Sci. 78: 1231-1255. 
Navarro-Alvarez W, Baenziger PS, Eskridge KM, Shelton DR, Gustafson VD and Hugo M (1994) Effect of sugars in wheat anther culture media. Plant Breeding 112: 53-62.

Nayak S, Debata BK and Sahoo S (1996) Rapid propagation of lemongrass (Cymbopogon flexuosus (Nees) Wats.) through somatic embryogenesis in vitro. Plant Cell Rep. 15: 367-70.

Nikolau BJ, Ohlrogge JB and Wurtele ES (2003) Plant biotin-containing carboxylases. Archives of Biochemistry and Biophysics 414: 211-222.

Phillips KA, Skirpan AL, Kaplinsky NJ and McSteen P (2009) Developmental disaster1 (Dvd1): A novel mutation causing defects during vegetative and inflorescence development in maize (Zea mays, Poaceae). Amer. J. Bot. 96: 420-430.

Qi J, Qian Q, Bu QY, Li SY, Chen Q, Sun JQ, Liang WX, Zhou YH, Chu CC and Li XG (2008) Mutation of the rice NARROW LEAF1 gene, which encodes a novel protein, affects vein patterning and polar auxin transport. Plant Physiol. 147: 1947-1959.

Roux JJL and Van Staden J (1991) Micropropagation and tissue culture of Eucalyptus - A Review. Tree Physiol. 9: 435-477.

Rudus I, Ke Pczyn E and Ke Pczynski J (2006) Comparative efficacy of abscisic acid and methyl jasmonate for indirect somatic embryogenesis in Medicago sativa L. Plant Growth Regul. 48: 1-11.

Sairam RV, Franklin G, Hassel R, Smith B, Meeker K, Kashikar N, Parani M, Al Abed D, Ismail S, Berry K and Goldman SL (2003) A study on the effect of genotypes, plant growth regulators and sugars in promoting plant regeneration via organogenesis from soybean cotyledonary nodal callus. Plant Cell Tiss. Org. Cult. 75: 79-85.

Selim SA (2011) Chemical composition, antioxidant and antimicrobial activity of the essential oil and methanol extract of the Egyptian lemongrass Cymbopogon proximus Stapf. Grasas y Aceites 62: 55-61.

Sidhu Y (2010) In vitro micropropagation of medicinal plants by tissue culture. The Plymouth Student Scientist 4: 432-449.

Streit WR, Joseph CM and Phillips DA (1996) Biotin and other water-soluble vitamins are key growth factors for alfalfa root colonization by Rhizobium meliloti 1021. Mol Plant microbe interact 9: 330-8.

Sul IW and Korban SS (2004) Effects of salt formulations, carbon sources, cytokinins, and auxin on shoot organogenesis from cotyledons of Pinus pinea L. Plant Growth Regul. 43: 197-205.

Suwitchayanon P and Kato-Noguchi H (2014) Allelopathic activity of leaves stalks and roots of Cymbopogon nardus. Emir. J. Food Agric. 26: 436-443.

Ueda J and Kato J (1982) Inhibition of cytokinin-induced plant growth by jasmonic acid and its methyl ester. Physiologia Plantarum 54: 249-252.

Wang DK, Pei KM, Fu YP, Sun ZX, Li SJ, Liu HQ, Tang K, Han B and Tao YZ (2007) Genome-wide analysis of the auxin response factors (ARF) gene family in rice (Oryza sativa). Gene 394: 13-24. 